\title{
W.E.B. DUBOIS'S “THE COMET” AND CONTRIBUTIONS TO CRITICAL RACE THEORY: AN ESSAY ON BLACK RADICAL POLITICS AND ANTI-RACIST SOCIAL ETHICS
}

\author{
Reiland Rabaka \\ University of Colorado at Boulder
}

\section{Critical Race Theory and the Riddle(s) of (Anti-)Race(ism)}

No longer considered the exclusive domain of legal studies scholars and radical civil rights lawyers and law professors, critical race theory has blossomed and currently encompasses and includes a wide range of theory and theorists from diverse academic disciplines. Its most prominent practitioners, initially law professors and "left scholars, most of them scholars of color" employing the work of the breathtakingly brilliant African American lawyer, scholar, and activist Derrick Bell (2005) as their primary point of departure, borrowed from many of the political and theoretical breakthroughs of black nationalism, anti-racist feminism, poststructuralism, and postmodernism. They also employed and experimented with new cutting-edge literary techniques and social science methodologies that shaped and shaded their work and burgeoning socio-legal discourse, ultimately giving it a fierceness and flair unheard of in the history of legal studies. Early critical race theorists' work acutely accented "the vexed bond between law and racial power" (Crenshaw, 
Gotanda, Peller \& Thomas, 1995, p. xiii). The emphasis on race and power quickly led them to the critique of "white supremacy and the subordination of people of color," not simply in the legal system, but in society as a whole (p. xiii).

Most notably, critical race theory essentially entails: a claim that race and racism are central to European modernity; an insistence that European modernity spawned a homogenizing social, political, legal and medical system that glosses over the heterogeneity of non-Europeans; a declaration that racism interlocks with sexism and classism to form an overarching system of oppression that thrice threatens modern movements for multicultural (and/or radical) democracy; a critique of the established order's claims of colorblindness and racially-neutral rule; a critique of whiteness and white supremacy; a call for racial justice; and lastly, a controversial claim that the raced (i.e., people of color) may have to employ race and their experiences of racism as a rallying point to mobilize a revolutionary anti-racist movement (Crenshaw, et al., 1995; Delgado, 1995; Delgado, Stefancic \& Harris, 2001; Essed \& Goldberg, 2001; Goldberg, Musheno \& Bower, 2001; Goldberg \& Solomos, 2002). W.E.B. Du Bois's philosophy of race in many senses foreshadows contemporary critical race theory and, therefore, contributes several paradigms and theoretic points of departure. However, as with so many other aspects of his thought, Du Bois's writings on race and racism have been relegated to the realm, at best, of sociology, which downplays and diminishes their interdisciplinarity and significance for contemporary critical social theory and radical politics (Rabaka, 2006b). Therefore, his writings on race have been virtually overlooked and/or rendered intellectually invisible by critical race theorists. With what follows I endeavor to fill this void in contemporary critical race scholarship by analyzing Du Bois's writings on race and racism as contributions to (the reconceptualization and reconstruction of) critical race theory.

In Critical Race Theory (1995), Richard Delgado states that though it began organizing as a "self-conscious entity" in 1989, critical race theory's "intellectual origins go back much further": "The movement has predecessors - Critical Legal Studies, to which it owes a great debt, feminism, and Continental social and political philosophy. It [also] derives its inspiration from the American civil rights tradition, including Martin Luther King, W.E.B. Du Bois, 
Rosa Parks, and Cesar Chavez, and from nationalist movements, including Malcolm X and the Panthers" (p. xiv). What I wish to highlight here is, first, though it generously draws from European and white American thought-traditions, African American social and political thought and movements have been at the heart of and enormously influential on critical race theory's discourse and debates. This is an important point to make since there has been a relative silence regarding critical race theory in African American Studies in specific, and Africana Studies more generally. If in fact African American radical intellectuals, social critics, and political activists have been at the heart of this discourse, central to its formation, and many of its major advocates and practitioners, then, African American Studies scholars and students would be remiss to continue to allow critical race theory to go unengaged."

A second issue I wish to emphasize here involves Du Bois's place in critical race scholarship. Many, if not all, of the key concerns of critical race theory are prefigured in Du Bois's discourse on race and racism in ways that makes one wonder whether critical race theory is simply a continuation, or a contemporary version of Du Boisian race theory by another name. Du Bois's critique of modernity, albeit often masked and muted, found it, modernity, morally weak and wanting because each of its inventions and innovations were accompanied by unprecedented human and environmental destruction and domination. Which is to say that when and where whites broke new ground, in whatever technical capacity and whichever area of existence, they did so on the graves of people of color, imperially embalming the earth and making the life-worlds, countries, and continents of people of color a massive mortuary. No amount of racial naïveté could save people of color. They therefore had no other recourse but to argue, as Du Bois did time and time again throughout his long career: race-consciousness, as will be discussed in greater detail below. At certain intervals in Du Bois's discourse this impulse registered as separatism, at others nationalism, and still others cultural internationalism. But, no matter which position Du Bois embraced and argued an anti-racist social ethics was ever at work and at the heart of his agenda and ultimate objectives (Edelin, 1981). Again, the emphasis on ethics made many of his positions - including and extending beyond his anti-racism - temporal tactics that were extremely time and space sensitive. 


\section{Du Bois's "The Comet" and/as Critical Race Theory}

One of the most intriguing issues that Du Bois's discourse on race and racism brings to the fore is the often-overlooked fact that it is possible to reject biology-based concepts of race and any and all forms of racism without denying the socio-historic and politico-economic reality of race and racism. The so-called "anti-race" theorists who argue that race and race-consciousness are the cause of racism and racial oppression are quite simply thinking wrong about race and have not done their homework on the origins and evolution(s), and the historic socio-political uses and abuses of race. Racism, as the critical race theorists never weary of reminding us, is "systematic" and, at this point, deeply "ingrained" in social, political, and cultural consciousness (Crenshaw et al., 1995, p. xiv). It is an invisible invader and an often-illusive intruder that has impacted and affected, perhaps, almost every life-experience human beings have had in the modern (and postmodern) moment. Even if utter abandonment of race concepts and race-consciousness were possible, the material and morphological, religious and rancorous, public and private consequences of the last five hundred years of extremely racialized human existence - that is, rote racialization and racial injustice and the socio-cultural memories associated with these phenomenon - would remain (see Goldberg, 1993, 1997, 2001; Mills, 1997, 1998). This is part of the point of Du Bois's short story, "The Comet" (1920), which dramatizes the persistent racial power relations between a black male "messenger" - or "courier," in contemporary jargon - named Jim Davis and a young wealthy white woman named Julia, after a comet has unleashed "deadly gases" that claim the lives of everyone in New York City (1996, p. 613). Jim, of course, represents African American or black thought and traditions, where Julia symbolizes European American or white thought and traditions. ${ }^{2}$

Even more than representing pre-apocalyptic black and white, hence, racial thought and traditions, Jim and Julia's journey, that is, their actual lived-experiences in a world where everyone else is dead, symbolizes an often uneasy transgression and transformation of previous (white supremacist and/or antiblack) racial thought and practices, that is, former racial views and values. An alternate interpretation of Jim and Julia as archetypal characters could also read them in a "religious" vein, 
as a post-apocalyptic Adam and Eve. Instead of a beautiful and peaceful "Garden of Eden," Du Bois places them in a world of death and ugliness, a world which metaphorically mirrors the one white folk imperially invented and orchestrated, especially considering the then recent bloodbath of World War I. However, Du Bois is quick to reveal, it is not a world of utter desolation and asphyxiation, so long as they free themselves from the vices and vulgarities of the former white supremacist world. This, of course, represents religious persons' life-long struggle to come to terms with the theodic thread that ironically undergirds and connects the religious traditions and expressions of those who worship and serve - to shamelessly steal a favorite phrase from black liberation theologian James Cone's critical language - the "God of the oppressed," and those who exalt and obey the "God of the oppressor" (Cone, 1975). In this vein, Jim and Julia's entire journey throughout, and experiences in, this world of death and disaster roughly boils down to a choice (the ultimate choice in the realm of religion) between God and the Devil, and/or good and evil. The "religious" interpretation of "The Comet" is given greater credence when we bear in mind Herbert Aptheker's assertion:

In all of his writings, the ready use of Biblical language [and symbolism] reflects that he was deeply read in both Testaments. However, Du Bois was not religious in a conventional sense, and he disliked organized religion. He was, however, deeply religious [read: spiritual] in that he believed in a kind of ultimate mystery in life, guided by some Creative Force; he also believed in a form of immortality. (1985, p. xii)

Though extremely intriguing, I will leave the "religious" interpretation of "The Comet" to critics better versed in the analysis of secular texts from a sacred frame of reference; hence, a certain sort of hermeneutics. My interpretation here, as I have intimated, will be almost utterly instrumental. I am interested specifically in the ways this short story foreshadows many of the motifs of critical race theory, and contributes to its reconceptualization and reconstruction by opening up a dialogue between critical race theorists and black radical intellectual-activists. Thus, this interpretation, like the story itself, is interdisciplinary, as it draws from African American literary, social, and cultural criticism, and also semiotic, Marxist, feminist, postmodern, and 
postcolonial theory. The primary purpose here is to produce an accessible analysis of Du Bois's contributions to the discourse and development of critical race theory and, in turn, critical race theory's contributions to the discourse and development of Africana critical theory (see Rabaka, 2002, 2003c, 2003d, 2003e, 2004, 2006a, 2006b).

"The Comet" offers us an ideal opportunity to observe Du Bois's contributions to critical race theory as it not only prefigures many of the themes taken up by contemporary critical race theorists, but it also pre-indicates some of the literary style(s) of current critical race theory. In Darkwater (1920), the volume which houses "The Comet," Du Bois employs a mixture of literary mediums, creating a textual collage that would have (or, maybe) made Romare Bearden grin from ear to ear. In a much more pronounced manner than in The Souls of Black Folk, Du Bois's writing in Darkwater was poignant and polyvocal, shifting back and forth between pungent politico-economic analysis and socio-cultural criticism to pure poetry and lyrical literary experimentation (the latter, à la Jean Toomer's 1923 classic Cane, though Du Bois's creative writing had a firmer foundation in the former, social science, and was, therefore, often cerebral and overly sentimental). Where The Souls of Black Folk was a literary look backward at the impact and effects of the African holocaust, enslavement, and Jim Crow segregation on the human pride and passions of African Americans, Darkwater was a literary look forward, a "vision of the liberated future" that Larry Neal (1989) and his Black Arts associates were soon to sing of. It was an extremely innovative and thoroughly cosmopolitan text, perhaps one of the first and most widely read to combine literary experimentation and sociological analysis with continental and diasporan African calls for racial justice. It was, amazingly for its time, simultaneously anti-racist, anti-sexist, anti-colonial, and anti-capitalist, devoting at least one chapter to each of the aforementioned issues and/or ideologies. It was, in the end, early Africana guerilla wordfare, to coin a phrase - that is, radical writing as a form of freedom fighting - in the sense that Du Bois employed every major modern style of writing to critique and combat the various types of domination and discrimination in his time and, sad to say, yet in ours. Let us now engage the story.

When the comet came, Jim, the messenger, was down in 
the Wall Street company's "lower vaults," "in the bowels of the earth, under the world," a place "too dangerous for more valuable men," his now deceased narrow-minded boss had told him. As a consequence of him being "down there," hard at work in the "dark basement beneath," he was spared the toxic smell of the comet's tail (Du Bois, 1996, p. 611). Julia, the young wealthy white woman, had been developing film in her plush, private darkroom, and was likewise spared. Jim bewilderingly discovered the death spell that had conquered New York City and immediately headed home to Harlem to check the life-status of his family. On his way he encountered Julia. Julia beckoned Jim from a great distance and, therefore, did not know that he was an African American - which seems beside the point since they are the only known survivors that each other are aware of in the whole of New York City, perhaps in the whole world. But, racism is dogged and rears its ugly head (and horns!), even during times of great duress and crisis, as Du Bois demonstrates, perhaps drawing directly from African Americans' recent experiences during and after World War I. Du Bois's depiction of Julia's reaction to being "saved" by a black man helps to highlight the continuing influence and effects of racism, however subtle, even in the event of the sudden absence of "races" and, more tellingly, white male racial rulers.

In some sense Du Bois can be seen as saying that Western European and white American culture are so thoroughly shotthrough with racism and the thousands of injustices, oppressions, and exclusions that accompany it, that it cannot quickly be unlearned even at the moment of crisis. White males do not have a monopoly on racist thought and behavior, though in white supremacist patriarchal polities they may be its most vocal and vicious proponents. This means, as Du Bois's short story suggests, in the absence of the white male racial ruler, the white woman (who is second to the white male in white supremacist social hierarchy and chain of command) shifts from being the eternal runner-up racial ruler to the head honcho racial ruler. Now turning to the text, the pertinent passage reads:

He came back on Fifth Avenue at 57th and flew past the Plaza and by the park with its hushed babies and silent throng, until he was rushing past 72nd Street he heard a sharp cry, and saw a living form leaning wildly out an upper window. He gasped. The human voice sounded 
in his ears like the voice of God...

He wheeled the car in a sudden circle, running over the still body of a child and leaping on the curb. Then he rushed up the steps and tried the door and rang violently. There was a long pause, but at last the heavy door swung back. They stared a moment in silence. She had not noticed before that he was a Negro. He had not thought of her as white. She was a woman of perhaps twenty-five - rarely beautiful and richly gowned, with darkly-golden hair, and jewels. Yesterday, he thought with bitterness, she would scarcely have looked at him twice. He would have been dirt beneath her silken feet. She stared at him. Of all the sorts of men she had pictured as coming to her rescue she had not dreamed of one like him. Not that he was not human, but he dwelt in a world so far from hers, so infinitely far, that he seldom even entered her thought. (p. 614)

To Jim, Julia's voice, the only other "human voice" he had heard in a world where everyone was dead, "sounded in his ears like the voice of God." Revealing just how temporal and tactical African American race-consciousness can be, Du Bois put Africana humanism on display, with Jim's initial thoughts of Julia being not that she was "white" and/or a "woman," but that she was human and in need of help. Jim's first impulse was to help the human being "leaning wildly" and hollering out of an upstairs window in the distance. That is the reason that Du Bois, a decidedly detailed and careful creative writer, did not write that Jim initially heard a "woman's voice," but a "human voice" that "sounded in his ears like the voice of God." In saying that the "human voice sounded in his ears like the voice of God," Du Bois is also associating this anonymous (raceless, genderless, and classless) human being that Jim is hearing and blurrily seeing in the distance, with God, with that which deserves and demands the utmost reverence in Africana spiritual traditions and worldviews. ${ }^{3}$

Julia's reaction to Jim is almost the antithesis of Jim's reaction to Julia. The very first thing that Julia notices is that Jim is a "Negro." Then, writes Du Bois, "She stared at him" (my emphasis). She may have stared at him in the irksome manner in which Du Bois writes that white people "eye[d]" or stared at him at the opening of The Souls of Black Folk: 
Between me and the other world there is ever an unasked question: unasked by some through feelings of delicacy; by others through the difficulty of rightly framing it. All, nevertheless, flirt round it. They approach me in a half-hesitant sort of way, eye me curiously or compassionately, and then, instead of saying directly, How does it feel to be a problem? they say, I know an excellent colored man in my town; or, I fought at Mechanicsville; or, Do not these Southern outrages make your blood boil? At these I smile, or am interested, or reduce the boiling to a simmer, as the occasion may require. To the real question, How does it feel to be a problem? I answer seldom a word. (1986, p. 363)

Du Bois makes his readers aware of the fact that Julia's stare, the way she "eyed [Jim] curiously or compassionately," with that white-"How does it feel to be a problem?"-look, unnerved him. Du Bois shares an irked Jim's inner monologue: "Yesterday, he thought with bitterness, she would scarcely have looked at him twice. He would have been dirt beneath her silken feet." It is only after Julia racializes the situation that Jim thinks, not of being racialist in retaliation, but of guarding himself against her highly probable racist or, at the least, racial reaction to seeing a black male rescuer at her front door. For Julia, "Of all the sorts of men she had pictured as coming to her rescue she had not dreamed of one like him." Why? Because, as Du Bois declared, "They [black men] are not simply dark white men. They are not 'men' in the sense that Europeans are men" (1995, p. 460). Julia had been taught this, and a million other minor things similar to this, all her life. Possibly unbeknownst to her, she had been taught to fear and hate black men, and black people more generally. Black people were only welcomed and wanted in the fallen, former white supremacist world when they were serving whites in whatever (usually docile and/or severely subordinate) capacity. Blacks were "good" when they did what whites wanted them to do. And, of course, blacks were "bad" when they had the audacity and unmitigated gall to pursue their all too human desires and political passions for freedom and justice. In the black existential world that Du Bois created in "The Comet," Jim was an unchecked black man, a seemingly rare being in the world of white supremacy, which is one of the reasons Julia's fear of both 
his blackness and maleness is heightened and increases as the story unfolds.

In spite of the eerie moment of racialization that pulled him back into the world of racial social conventions and interpersonal politics, Jim treated Julia with the utmost care and human consideration, so much so that after being in his presence for a short time she "looked at him now with strength and confidence": "He did not look like men, as she had always pictured men; but he acted like one and she was content" (Du Bois, 1996, p. 616). Here Du Bois is highlighting and hinting at a couple of things; first, the fact that though Jim did not look like the men or human beings that Julia was accustomed to, he nevertheless carried himself in humble dignity and accorded her in a humane and moral manner. That is to say, though Julia unfairly initially judged and devalued Jim based on his biology, he, in the words of Frantz Fanon, in Black Skin, White Masks, refused to be "the slave of the past" (1967, p. 225). With each of his words and actions, Jim seemed to be saying:

Like it or not, the past can in no way guide me in the present moment...

I will not make myself the man of any past. I do not want to exalt the past at the expense of my present and of my future...

I can recapture my past, validate it, or condemn it through my successive choices...

I do not have a duty to be this or that....

If the white man challenges my humanity, I will impose my whole weight as a man on his life and show him that I am not that "sho' good eatin" that he persists in imagining.

I find myself suddenly in the world and I recognize that I have one right alone: That of demanding human behavior from the other.

One duty alone: That of not renouncing my freedom through my choices. (pp. 225-229)

Jim chose to suspend and/or side-step the social conventions of the white supremacist past in an effort to create a moral and multicultural present and future. He was, or, at the least, he quickly became the antithetical living embodiment of what Julia had learned about African American men, and African Americans 
more generally. But, regrettably, none of this dissipated Julia's deep-seated fear and hatred of blacks. At the first opportunity, she ran away from the only living soul in New York City, simply because that soul was housed in a black body.

It was too mighty - too terrible! She turned toward the door with a new fear in her heart. For the first time she seemed to realize that she was alone in the world with a stranger, with something more than a stranger, - with a man alien in blood and culture - unknown, perhaps unknowable. It was awful! She must escape - she must fly; he must not see her again. Who knew what awful thoughts -

She gathered her silken skirts deftly about her young, smooth limbs - listened, and glided into a side-hall. A moment she shrank back: the hall lay filled with dead women; then she leaped to the door and tore at it, with bleeding fingers, until it swung wide. She looked out. He was standing at the top of the alley, - silhouetted, tall and black, motionless. Was he looking at her or away? She did not know - she did not care. She simply leaped and ran — ran until she found herself alone amid the dead and the tall ramparts of towering buildings.

She stopped. She was alone. Alone! Alone on the streets - alone in the city - perhaps alone in the world! There crept in upon her the sense of deception - of creeping hands behind her back - of silent, moving things she could not see, - of voices hushed in fearsome conspiracy. She looked behind and sideways, stared at strange sounds and heard still stranger, until every nerve within her stood sharp and quivering, stretched to scream at the barest touch. She whirled and flew back, whimpering like a child, until she found that narrow alley again and the dark silent figure silhouetted at the top. She stopped and rested; then she walked silently toward him, looked at him timidly; but he said nothing as he handed her into the car. (Du Bois, 1996, p. 617)

Why would Julia run away from Jim, literally, the only living person in the whole of New York City, perhaps even the world? 
Why is it that even though she knows Jim (who has treated her with the utmost respect) is there with her, she feels "Alone! Alone on the streets - alone in the city - perhaps alone in the world!"? Because, as Fanon - echoing Du Bois - perceptively pointed out in Black Skin, White Masks: the black man is not a man, but a "nigger." You see, "A man was expected to behave like a man. I was expected to behave like a black man - or at least like a nigger," and "The Negro is an animal, the Negro is bad, the Negro is mean, the Negro is ugly" (Fanon, 1967, p. 114). Julia leads us to conclude this with her "Who knew what awful thoughts - [he may have had or, worst, be having?!]" statement. Which, of course, is a reference to the myth of the black rapist that was then circulating and extremely popular as a result of Thomas Dixon's best-selling novel, The Clansman (1905), and the movie it spawned, D.W. Griffith's Birth of a Nation (1915). What is amazing and ironic, though, is that Julia thought all of this after Jim forgave her initial racist predilections and treated her as a sister in the house of humanity.

Julia judged Jim not as an individual, but based on her white supremacist prejudgments and prefabrications of the black race. To her, Jim was not a black man, but a black beast that her white father and husband-to-be had been burdened with, "half-devil and half-child," as Du Bois prickly put it (1995, p. 460). Jim was, in the words of Fanon, "overdetermined from without" (Fanon, 1967, p. 116). Julia, the default racial ruler in the absence of the white patriarch(s), would not allow Jim and his "tom-toms, cannibalism, intellectual deficiency, fetishism, racial defects, slave-ships, and above all else, above all: "Sho' good eatin'," to be or become human (p. 112). He would be held down, as he always had been, "kept in his place," as it were, just as the physically absent though ideologically present white father and fiancé would have it. She, and precisely she alone, would uphold the ways of the white supremacist (and patriarchal!) world, even if that meant, literally, running from life to death. This, of course, symbolizes Julia's second breach of Jim's efforts to bring into being a new moral and multicultural world. However, when Julia's white supremacist fit subsides, and she returns to the apocalyptic present reality without races, Jim - not in the fashion of the good and faithful "darkie," but in the morally firm and forward-thinking spirit of, say, Frederick Douglass and Frances Harper - forgives her of her 
racist prepossessions and proclivities a second time. He soberly suggests that they continue their search for other survivors, which intimates two things.

First, it accents black resilience and spirituality in the face of human misery and senseless suffering. In other words, Jim's decision to move on speaks to Africana peoples' impulse to go on no matter what the odds, circumstance, or situation. Thus, this connects Darkwater (the book which houses "The Comet") with The Souls of Black Folk, and particularly its opening chapter, "Of Our Spiritual Strivings," which prosaically documents and details black folks' use of their spirituality and quickly (re)forming culture to overcome, perhaps, the greatest collective adversities in Africana history: the African holocaust, colonization, enslavement, and subsequent segregation. Second, and closely connected to the first point, Jim's rectitude and unreluctant willingness to continue the search for survivors symbolizes the Africana emphasis on ethics when reasoning racially. Like many of his enslaved ancestors and political progeny in the soon-coming Civil Rights movement, he would not lower himself to a racial reactionary and/or "reverseracist" level. He knew, as Audre Lorde asserted in Sister Outsider, "it is the responsibility of the oppressed to teach the oppressors their mistakes" (1984, p. 114). He knew, again as Lorde laid bare, "Once you live any piece of your vision it opens you to constant onslaught" (p. 107). Jim withstood Julia's brutal racial blows and, with reconciliatory tears in her eyes and his hurt heart covered and chin up, they continued the search. But, not without Julia soon thereafter having an incredible racial revelation as a consequence of Jim's anti-racist ethics.

Jim's anti-racist ethics in this instance would have made Martin Luther King, Jr. marvel, because it cut to the core of Julia's racial consciousness and made her reconsider her racial reasoning and Jim's (and his peoples') humble humanity. Even in the face of a second racial betrayal Jim was merciful and "made her comfortable," finding them safe carnageless shelter and preparing food - though, I revel in reporting, not in the Fanonian "sho' good eatin'!" fashion. In addition - and this is a turning point - he "timidly...took a shawl and wound her in it, touching her reverently, yet tenderly" (Du Bois, 1996, p. 619). Now as "[h]e watched the city. She watched him. He seemed very human, very near now." The dye was cast, and Jim and Julia spoke as if it 
were their first time speaking, reflecting on the world as it was, and as it was to be:

"Have you had to work hard?" she asked softly.

"Always," he said.

"I have always been idle," she said. "I was rich."

"I was poor," he almost echoed.

"The rich and the poor are met together," she began, and he finished:

"The Lord is the Maker of them all."

"Yes," she said slowly; "and how foolish our human distinctions seem - now," looking down to the great dead city stretched below, swimming in unlighted shadows. "Yes - I was not - human, yesterday," he said.

She looked at him. "And your people were not my people," she said; "but today_-" She paused. (p. 619)

Moving many of the more familiar social markers and social barriers, Du Bois presents a dialogue that is a simultaneously simple and complex study in racial, sexual, and class differences. He begins with class differences, emphasizing that where the black has always worked, the white has "always been idle," figuratively speaking. Death and disaster brought "the world of poverty and work" and "the world of wealth and prosperity" together (p. 617). As in so many Africana religious traditions, death is not simply an end, but also a beginning. Du Bois, waxing utopian here, demonstrates the awesome and ironic power of death to give new life when he has the characters refer to their class positions in the past tense. Julia says, "I was rich," and Jim remarks, "I was poor" (my emphasis). Does this mean, then, that Julia was "white," and Jim was "black"? The text suggests as much when Julia, the former racial ruler, says, "how foolish our human distinctions seem - now." Jim unapologetically answers, "Yes - I was not - human, yesterday." A new day has dawned, and Julia and Jim may very well be the forerunners to the "new men" and "new humanity" that Fanon wrote about in The Wretched of the Earth (1968, p. 36).

It is also interesting to observe that Jim had been subtly and sincerely trying to share his (and his peoples') vision of a "new humanity" with Julia their entire journey. But, blinded by the white supremacist views and values of yesterday, Julia could not see. It took Jim unerringly practicing anti-racist ethics to open 
her eyes. And now what does Julia see? "He was a man, - no more; but he was in some larger sense a gentleman, - sensitive, kindly, chivalrous, everything save his hands and - his face" (Du Bois, 1996, p. 619). As a result of his strict adherence to his (and his peoples') anti-racist ethics, in Julia's eyes jim went from subhuman to human to, virtually, superhuman - his hands and face withstanding.

Why, we are quick to query, his hands and face withstanding? Because Du Bois wanted to preserve the mark of difference. Even in Utopia blacks can never forget the lived-experiences and lifelessons of the former anti-black world, which is one of the reasons Jim's hands will continue to be rough, as a reminder of yesterday's years and years of hard work and harsh labor conditions. His face would remain distinct because the black face and head have ever been one of the most contested sites and sources of cultural valuation and degradation, and also one of the greatest markers of Africana identity (dare I say "ancestry"). In the final analysis, Jim's journey to Utopia had been, in several senses, the antithesis of Julia's, and his hands and face would continue to tell the dark tale.

Just as Fanon would explain it forty years later in The Wretched of the Earth, Jim's anti-racist ethics transformed both the colonized and the colonizer, or rather, in this instance, the raced and the racial ruler. In Fanon's words, "the 'thing' which has been colonized becomes [hu]man during the same process by which it frees itself" (1968, p. 37). At the beginning of "The Comet" Du Bois revealed regarding Jim, his social status and sense of self-worth: "Few noticed him. Few ever noticed him save in a way that stung. He was outside the world - 'nothing!' as he said bitterly" (Du Bois, 1996, p. 611). Now Jim was at the center of the world, and regarded by the only other surviving soul as human, not simply because he was the only other human being left alive but because of his anti-racist ethics. This had a profound impact on Jim, who once thought of himself as "outside of the world - 'nothing!" Now,

Memories of memories stirred to life in the dead recesses of his mind. The shackles seemed to rattle and fall from his soul. Up from the crass and crushing and cringing of his caste leaped the lone majesty of kings long dead. He arose within the shadow, tall, straight, and stern, 
with power in his eyes and ghostly scepters hovering to his grasp. It was as though some mighty Pharaoh lived again, or curled Assyrian lord. (p. 620)

In a sense, Jim freed himself and Julia from the vices and vulgarities of white supremacy, and in the end he was reconnected with the very past which white supremacy had long attempted to culturally thieve and hide from him and his people. ${ }^{\text {The "shackles" }}$ and chains, symbolizing he and his peoples' enslavement (both de jure and de facto), fell "from his soul." He held "the lone majesty of kings long dead," "[i]t was as though some mighty Pharaoh lived again, or curled Assyrian lord." Jim was royal, and entered the spiritual court of kings and queens predicated not on any authoritarianism or elitism (à la Du Bois's early articulation of the "Talented Tenth"), but based on his public and personal ethics (see Rabaka, 2003b, 2005).

However, and not to sound cynical, his heaven on earth was short-lived. Just as he and Julia were both contemplating their post-racial revelations and the future, they heard the honk of a car horn. Immediately, she "covered her eyes with her hands, and her shoulders heaved. He dropped and bowed, groped blindly on his knees about the floor" (p. 620). The white father and fiancé soon thereafter burst into the room. The world was not lost, "[o]nly New York" (p. 621). After tending to the white damsel in distress, the father and fiancé took note of Jim. The fiancé was, of course, perplexed: "Suddenly he stiffened and his hand flew to his hip. 'Why!' he snarled. 'It's—a-nigger-Julia! Has he-has he dared"(p. 621). Julia informs them that, "He has dared-all, to rescue me,' she said quietly, 'and I-thank him—much.' But she did not look at him again" (p. 621). Jim was back in the world of white supremacy. He was negro persona non grata again. He was black, and she was white, and no matter what racial transgressions and transformations they experienced, these breakthroughs would not be translated to the wider (or, rather, racially ruling white) world without both of them ardently espousing and sharing their new anti-racist knowledge. In this context (that of the return of white supremacist patriarchy) Julia had to take the moral lead, as Jim had previously in the world without white supremacist patriarchy. But, she did not and the all too familiar racial regression that is characteristic of black/white interpersonal interactions in white supremacist society resumed its reign. 
Julia "did not look at him again," because he did not register as human anymore. He was "black" (or, worst, a "nigger") and, therefore - to resonate with Ralph Ellison -invisible. Where Jim once, however recent and momentarily, felt like a king, hearing the car horn reversed his feelings and flung him back into the world of white supremacy, which is one of the reasons Du Bois tells us at hearing the car horn he "dropped and bowed, groped blindly on his knees about the floor." Jim prostrated himself as though he were in the presence of a princess. It is almost as if he knew Julia would morally and racially betray him a third time, and this is where the story ends. Barely getting out of the presence of the white supremacist patriarchs without being lynched, as it was suggested several times by on-looking white supremacist patriarchs, Jim is reunited with his wife and is told of the death of their child. The black child's death symbolizes the bleakness of black folks' future, the continued denial of black humanity and dignity, and blacks' ultimate non-existence in the future white supremacist world.

\section{Reconceptuailizing and Reconstructlng Crltlcal Race Theory}

What does all (or any) of this have to do with critical race theory? Quickly and in conclusion, there are several critical race themes strewn throughout the story. Du Bois twists and turns many of the motifs in ways that are at once interesting and invigorating. First, consider Du Bois's emphasis on and critique of the racial (and racist) dimensions of class (contemporary white Marxists should take note). Critical race theorists argue that racism exacerbates class and creates the very chasm (or, "veil," in Du Bois's discourse) between whites and non-whites that Du Bois detailed in his story (Delgado \& Stefancic, 2001; Ford, 1995; Mills, 2003). Hence, Julia stated that Jim "dwelt in a world so far from hers, so infinitely far, that he seldom even entered her thought." White supremacy, and all of the racial exclusions that accompany it, place nonwhites well beyond the pale of human consideration because it is only whites who are and can be considered "human" and register as such on the social barometer of a white supremacist world. Class struggle in a white supremacist world, then, cannot help but to take on a racial character because race in a race supremacist context is never neutral, but always and ever political and deeply 
connected to economic power and privileges or economic disadvantages and disenfranchisements (Mills, 1987, 2003).

Second, Du Bois's short story suggests that more radical measures than mere piecemeal socio-political reform and reluctant gradualism are needed to make the system an authentic multicultural democracy, as opposed to what Charles Mills (1998, pp. 139-166) has termed a "Herrenvolk" or ruling race democracy. There is a sense in which "The Comet" can be read as a racially oppressed and poverty-stricken person's dream come true, not in any racially malicious or morally repugnant sense but in a Fanonian sense, in terms of the oppressed desperately desiring to see their oppressors and the oppressive system they imperially invented toppled. The story is also Fanonian in the sense that there is room for racial reconciliation and redemption if - and this is an extremely important "if" that cannot be over-emphasized - if they both free themselves from the social conventions, vices, and vulgarities of the former white supremacist world.

More than once Jim, symbolic of the oppressed race-class, demonstrates his rectitude regarding race and, by the end of the story, Julia, symbolic of the oppressing race-class, learned a lesson in anti-racist social ethics from him (or, did she?). This connects with the discourse of critical race theory when we bear in mind that part of its criticism is directed at the established order's claims of colorblindness and racially-neutral rule (Bell, 1995; Gotanda, 1995; Lee, 1995; Lopez, 1995, 1996). Jim did not politely tip-toe around race and racism. He knew he was not considered human by white supremacist social standards and, therefore, based on her initial racial reaction, was not regarded as a human being by Julia. Here he follows Fanon and nods tothe critical race theorists, as he refuses to allow a racist system and/or a racist individual associated with that system to question and/or deny his humanity and dignity. He did precisely what Fanon suggested above, he brought his "whole weight" as a human being to bear on Julia and showed her that he was "not that 'sho' good eatin' that [s] he persist[ed] in imagining." In other words, and in critical race lingo, Jim spoke radical anti-racist truth to racist power. He was not put off by Julia's age or gender, and he realized early on that white men have no monopoly on racist thought and behavior: white supremacy has infected, so it seems, the whole of the white race (Allen, 1994, 1997; Delgado \& Stefancic, 1997; Harris, 1995). 
Finally, Julia's decision to racially regress at the end of the story by rendering the previously visible Jim an invisible black, or "nigger," as her fiancé would have it, symbolizes not simply the return of white supremacist patriarchy, but it also represents one of the main reasons critical race theorists endorse race-consciousness as a counter to white racism (Guiner, 1995; Peller, 1995). Kimberlé Crenshaw and company claim: "With its explicit embrace of race-consciousness, Critical Race Theory aims to reexamine the terms by which race and racism have been negotiated in American consciousness, and to recover and revitalize the radical tradition of race-consciousness among African Americans and other peoples of color - a tradition that was discarded when integration, assimilation and the ideal of color-blindness became the official norms of racial enlightenment" (Crenshaw et al., 1995, pp. xiv). Along these lines, "The Comet" illustrates critical race theorists' key claim regarding race-consciousness: that it will never be enough for the racially oppressed to repudiate racism. Though anti-racism has and more than likely will always primarily emanate from the realm of the racially oppressed, for it to be most effective both the racially ruled and the racial rulers must mutually repudiate racism. Du Bois demonstrated what will happen if all of the onus is placed on the racially ruled: they will end up, literally, parodying and prostrating themselves each time they are in the hallowed presence of whiteness. Unless and until the racial rulers relinquish race and rid themselves of racism, the racially ruled have no other recourse (at this point) but to cautiously employ race as a socio-political vehicle to counter racism and create anti-racist theory and revolutionary praxis.

\section{Notes}

'There have, of course, been exceptions, more or less intellectual flirtations as opposed to constructive critical dialogue between critical race theorists and Africana Studies scholars. For instance, works such as Collins (2003), Gordon (1999), and Outlaw (1990). However, these works are more in the realm of intellectual history, sort of clocumenting the often-omitted Africana climension of critical race theory. What I propose to clo here is to use Du Bois as a theoretic point of cleparture to highlight and accent the major themes of critical race theory as it is currently practiced. In addition, my work here also endeavors to place 
new issues on critical race theory's agenda, issues that will continue to be downplayed and diminished until Du Bois's anti-racist discoveries (among many other black anti-racist radicals) are critically engaged for their contribution to contemporary race and racism discourse. For further cliscussion, see Rabaka (2006a, forthcoming).

${ }^{2}$ In his creative writings, Du Bois often used characters in an archetypal and/or symbolic sense, as representing not so much their own individual impulses, but the ideals and aspirations of their people, cultures, countries, and communities. This, of course, often overly racialized and bogged his characters down with what could be termed idealism, usually giving them utopian (and frequently radical political or Left) leanings. But, this archetypal idealization and racialization of his characters also gave them a startling realism that is as telling about Du Bois's racial and cultural thought as it is about the times in which he was writing. Needless to say, Du Bois's creative writings always retained a level of scholasticism that made them fiction in form, nonfiction in subject matter, and often experimental and innovative in style (see Du Bois, 1985). For further discussion of Du Bois as a littérateur, see Byerman (1994), Rampersad (1990), Stewart (1983), and Sundquist (1993).

${ }^{3}$ This interpretation of God, God's relationship with human beings, and human beings reverence for God (and the deities associated with God) in Africana spiritual traditions has been informed by: Blakely, van Beek \& Thomson (1994), Du Bois (2000), Fulop \& Raboteau (1996), and Ray (2000).

${ }^{4}$ The hidden history theme runs throughout Du Bois's corpus and informs his historical writing, fiction, gift theory, and socio-political thought, among other aspects of his philosophy and intellectual framework. Needless to say, none of the aforementioned carries the critical weight and gravity of history. History had a special place in Du Bois's social and political theory, as it provided human beings with a map of the past social world and markers that might be useful in efforts to chart (and change!) the present social world. This made history especially important to continental and diasporan Africans because white supremacy and other forms of anti-African racism were predicated on false claims that Africans had no history and, therefore, had not made any contributions to human culture and civilization. In a high-handed sense, history documents and details human triumphs and tragedies. Therefore, if and when Africans did register in white historical records, it was only in the latter tragic sense, which ultimately gave way to the black pathology discussions of Eurocentric historical discourse. For more detailed discussions of Du Bois as historian and his philosophy of history, see 
Blight (1994), Gooding-Williams (1987), Rabaka (2003b), and Robinson (2000).

\section{Acknowledgements}

I am inclelibly inclebted to several intellectual-activists who have contributed (either directly or indirectly) to my conception(s) of philosophy of race, sociology of race, critical race theory, critical social theory, and radical politics. A humble and heartfelt asante sana (many thanks) goes to: Marilyn Giles, Lucuis Outlaw, Rahsaan Roland Kirk, Kristine Lewis, Rhonda Tankerson, Mark Christian, Patrick DeWalt, Anthony Lemelle, Lamya Al-Kharusi, Kimberly Marshall, and my colleagues at the Center for Studies of Ethnicity and Race in America (CSERA) at the University of Colorado at Boulder.

\section{References}

Allen, T.W. (1994). The Invention of the White Race, volume 1. New York: Verso.

York: Verso.

(1997). The Invention of the White Race, volume 2. New

Aptheker, H. (1985). Introduction to Du Bois's Creative Writings. In H. Aptheker (Ed.), Creative Writings by W.E.B. Du Bois: A Pageant, Poems, Short Stories, and Playlets (pp. ix-xii). White Plains, NY: Kraus International.

Bell, D. (1995). Racial Realism After We're Gone: Prudent Speculations on America in a Post-Racial Epoch. In R. Delgado (Ed.), Critical Race Theory (pp. 2-8). Philadelphia: Temple University Press.

. (2005). The Derrick Bell Reader (R. Delgado \& J. Stefancic, Eds.). New York: NYU Press.

Blakely, T.D., van Beek, W.E.A., and Thomson, D.L. (Eds.). (1994). Religion in Africa. London: Curry \& Lang.

Blight, D.W. (1994). W.E.B. Du Bois and the Struggle for American Historical Memory. In G. Fabre and R. O Meally (Ecls.), History and Memory in African American Culture (pp. 63-89). New York: Oxford University Press.

Byerman, K.E. (1994). Seizing the Word: History, Art, and Self in the Work of W.E.B. Du Bois. Athens: University of Georgia Press. 
Collins, L.E. (2002). Critical Race Theory: Themes, Perspectives, and Directions. In J.L. Conyers, Jr. (Ed.), Black Cultures and Race Relations (pp. 154-168). Chicago: Burnham.

Cone, J.H. (1975). God of the Oppressed. New York: Seabury Press.

Crenshaw, K., Gotanda, N., Peller, G., and Thomas, K.. (Eds.). (1995). Critical Race Theory: The Key Writings That Formed the Movement. New York: New Press.

Delgaclo, R. (Ed.). (1995). Critical Race Theory: The Cutting Eclge. Philadelphia: Temple University Press.

Delgado, R., and Stefancic, J. (Eds.). (1997). Critical White Studies: Looking Behind the Mirror. Philadelphia: Temple University Press.

Delgado, R., and Stefancic, J. (2001). Critical Race Theory: An Introduction. New York: New York University Press.

Du Bois, W.E.B. (1969). Darkwater: Voices from Within the Veil. New York: Schocken.

(1985). Creative Writings by W.E.B. Du Bois: A Pageant, Poems, Short Stories and Playlets (H. Aptheker, Ed.). Millwood, NY: Kraus-Thomson.

Library of America Press.

(1986). Du Bois: Writings (N.I. Huggins, Ed.). New York: . (1995). W.E.B. Du Bois Reader (D.L. Lewis, Ed.) New York: Henry Holt.

. (1996). The Oxford W.E.B. Du Bois Reader (E. Sundquist, Ed.). New York: Oxford University Press.

. (1997). The Souls of Black Folk (R. Gooding-Williams and D.W. Blight, Eds.). Boston: Bedford Books.

nut Creek: Altamira.

(2000). Du Bois on Religion (P. Zuckerman, Ed.). Wal(2002). Du Bois on Education (E.F. Provenzo, Jr., Ed.).

Walnut Creek: Altamira. 


\section{Ethnlc Studles Revlew Volume 29}

(2004). The Social Theory of W.E.B. Du Bois (P. Zuckerman, Ed.). Thousand Oaks: Sage.

Edelin, R.H. (1981). The Philsophical Foundations and Implications of William Edward Burghardt Du Bois's Social Ethic. Ph.D. dissertation, Boston University Graduate School.

Essed, P., and Goldberg, D.T. (Ecls.). (2001). Race Critical Theories: Texts and Contexts. Malclen: Blackwell.

Fanon, F. (1967). Black Skin, White Masks. New York: Grove.

(1968). The Wretched of the Earth. New York: Grove.

Ford, R.T. (1995). The Boundaries of Race: Political Geography in Legal Analysis. In Crenshaw, Gotancla, Peller \& Thomas (Ecls.), Critical Race Theory (pp. 449-464). New York: New Press.

Fulop, T., and Raboteau, A.J. (Eds.). (1996). African American Religion: Interpretive Essays in History and Culture. New York: Routledge.

Goldberg, D.T. (Ed.). (1990). Anatomy of Racism. Minneapolis: University of Minnesota Press.

(1993). Racist Culture: Philosophy and the Politics of Meaning. Cambridge: Blackwell.

. (Ed.). (1994). Multiculturalism: A Critical Reader. Cambriclge: Blackwell.

(1997). Racial Subjects: Writing on Race in America. New

York: Routledge. (2001). The Racial State. Malden, MA: Blackwell.

Goldberg, D.T., Musheno, M., and Bower, L. (Ecls.). (2001). Between Law and Culture: Relocating Legal Studies. Minneapolis: University of Minnesota Press.

Goldberg, D.T., and Quayson, A. (Ecls.). (1999). Relocating Postcolonialism: A Critical Reader. Malden, MA: Blackwell.

Goldberg, D.T., and Solomos, J. (Ecls.). (2002). A Companion to Racial and Ethnic Studies. Malclen: Blackwell. 
Goodin, P. (2002). Du Bois and Appiah: The Politics of Race and Racial Identity. In R.E. Birt (Ed.), The Quest for Community and Identity: Critical Essays in Africana Social Philosophy (pp. 73-83). Lanham, MD: Rowman \& Littlefield.

Gooding-Williams, R. (1987). Philosophy of History and Social Critique in The Souls of Black Folk. Social Science Information 26, 99-114.

Gordon, L.R. (1999). A Short History of the 'Critical' in Critical Race Theory. APA Newsletter on Philosophy and the Black Experience 98, 2, 23-26.

Gotanda, N. (1995). A Critique of 'Our Constitution is Color-Blind'. In Crenshaw, Gotanda, Peller \& Thomas (Ecls.), Critical Race Theory (pp. 257-275). New York: New Press.

Guiner, L. (1995). Groups, Representation, and Race-Consciousness Districting: A Case of the Emperor's Clothes. In Crenshaw, Gotanda, Peller \& Thomas (Ecls.), Critical Race Theory (pp. 205-234). New York: New Press.

Harris, C.I. (1995). Whiteness as Property. In Crenshaw, Gotanda, Peller \& Thomas (Ecls.), Critical Race Theory (pp. 276-291). New York: New Press.

Lee, J.C. (1995). Navigating the Topology of Race. In Crenshaw, Gotanda, Peller \& Thomas (Ecls.), Critical Race Theory (pp. 441-448). New York: New Press.

Lopez, I.F.H. (1995). The Social Construction of Race. In R. Delgado (Ed.), Critical Race Theory (pp. 191-203). Philadelphia: Temple University Press.

(1996). White by Law: The Legal Construction of Race. New York: New York University Press.

Lorde, A. (1984). Sister Outsider: Essays and Speeches by Audre Lorde. Freedom, CA: The Crossing Press Feminist Series.

Firebrand.

(1988). A Burst of Light: Essays by Audre Lorde. Ithaca, NY:

Mills, C.W. (1987). Race and Class: Conflicting or Reconcilable Paradigms? Social and Economic Studies 36, 2, 69-108. 
Press.

. (1997). The Racial Contract. Ithaca: Cornell University

(1998). Blackness Visible: Essays on Philosophy and Race. Ithaca: Cornell University Press.

(2000). Race and the Social Contract Tradition. Social Identities: A Journal for the Study of Race, Nation and Culture 6, 4, 441-462.

(2001). White Supremacy and Racial Justice. In J. Sterba (Ed.), Social and Political Philosophy: Contemporary Perspectives (pp. 321-337). New York: Routledge.

. (2003). From Class to Race: Essays in White Marxism and Black Radicalism. Lanham, MD: Rowman \& Littlefield.

Neal, L. (1989). Visions of a Liberated Future: Black Arts Movements Writings. New York: Thunder's Mouth Press.

Outlaw, L. (1990). Toward a Critical Theory of 'Race'. In D.T. Goldberg (Ecl.), Anatomy of Racism (pp. 58-82). Minneapolis: University of Minnesota Press.

Peller, G. (1995). Race-Consciousness. In Crenshaw, Gotanda, Peller \& Thomas (Eds.), Critical Race Theory (pp. 127-158). New York: New Press.

Rabaka, R. (2002). Malcolm X and/as Critical Theory: Philosophy, Radical Politics, and the African American Search for Social Justice. Journal of Black Studies 33, 2, 145-165.

(2003a). I Found Myself in His Words: Reflections on the Centennial of W.E.B. Du Bois's The Souls of Black Folk. Newark Reads Du Bois Newsletter. Newark, NJ: Institute on Ethnicity, Culture, and the Modern Experience, Rutgers University-Newark. Available at: http://andromeda.rutgers.edu/ history/DuBois/rabaka.html [3 February 2003].

. (2003b). W.E.B. Du Bois's Evolving Africana Philosophy of Education. Journal of Black Studies 33, 4, 399-449.

. (2003c). 'Deliberately Using the Word Colonial in a Much Broader Sense': W.E.B. Du Bois's Concept of 'Semi-Colonialism' as Critique of and Contribution to Postcolonialism. Jouvert: A Journal of Post- 
colonial Studies 7, 2, 1-32. Available on-line at: http://social.chass.ncsu. edu/jouvert/index.htm [23 February 2003].

. (2003d). W.E.B. Du Bois and/as Africana Critical Theory: Pan-Africanism, Critical Marxism, and Male-Feminism. In J.L. Conyers (Ed.), Africa and the Academy (pp. 67-112). Jefferson, NC: McFarland \& Co.

(2003e). W.E.B. Du Bois and 'The Damnation of Women': An Essay on Africana Anti-Sexist Critical Social Theory. Journal of African American Studies 7, 2, 39-62.

. (2004). The Souls of Black Female Folk: W.E.B. Du Bois and Africana Anti-Sexist Critical Social Theory. Africalogical Perspectives 1 , 2, 63-97.

. (2005). W.E.B. Du Bois's Theory of the Talented Tenth. In M.K. Asante and A. Mazama (Eds.), The Encyclopedia of Black Studies (pp. 443-445). Thousand Oaks, CA: Sage.

(2006a). Africana Critical Theory of Contemporary Society: Ruminations on Radical Politics, Social Theory, and Africana Philosophy. In M.K. Asante \& M. Karenga (Eds.), The Handbook of Black Studies (pp. 130-152). Thousand Oaks, CA: Sage.

(2006b). The Souls of Black Radical Folk: W.E.B. Du Bois, Critical Social Theory, and the State of Africana Studies. Journal of Black Studies 36 (5), 69-101.

. (forthcoming). W.E.B. Du Bois, Reparations, Radical Politics, and Critical Race Theory. Africana Studies Annual Review.

Rampersad, A. (1990). The Art and Imagination of W.E.B. Du Bois. New York: Schocken.

Ray, B.C. (2000). African Religions: Symbol, Ritual, and Community. Upper Saddle, NJ: Prentice Hall.

Robinson, C.J. (2000). Black Marxism: The Making of the Black Radical Tradition. Chapel Hill: University of North Carolina.

Stewart, J.B. (1983). The Psychic Duality of Afro-Americans in the Novels of W.E.B. Du Bois. Phylon 44, 2, 93-107. 


\section{Ethnlc Studles Revlew Volume 29}

(1984). The Legacy of W.E.B. Du Bois for Contemporary

Black Studies. Journal of Negro Education 53, 296-311.

Sundquist, E.J. (1993). To Wake the Nations: Race in the Making of American Literature. Cambridge: Harvard University Press.

Toomer, J. (1993). Cane. New York: Liveright. 